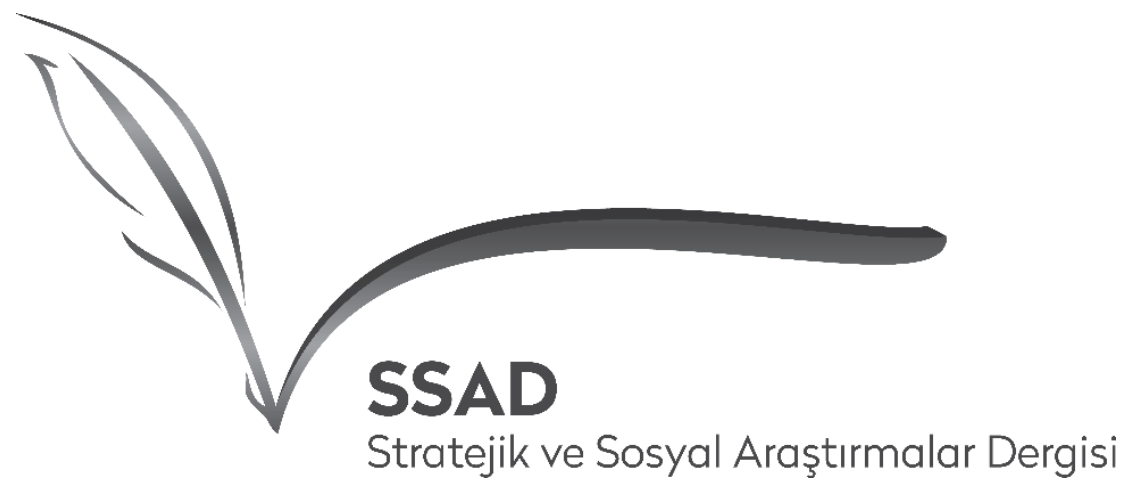

ISSN: 2587-2621

Volume 2 Issue 1, July 2018

\title{
TARIHİ OLAYLAR BAĞLAMINDA ABBÂSÎLER DÖNEMİ ALTIN VE GÜMÜŞ SİKKELERİ
}

\section{Gold And Silver Coins In The Abbasid Period In The Context of Historical Events}

\section{Günnur AYDOĞDU*}

Öz: Bu çalışmada, günümüze ulaşabilmiş örnekler 1şı̆̆ında, Abbâsîler Dönemine ait sikkelerin tasarım, kompozisyon ve uygulama anlamında kronolojik olarak sergiledikleri temel değişim/gelişim aşamalarının belirlenmesi ve sonuçta ilgili dönemin sikke basımı seyrinin somut olarak algılanabilmesi amaçlanmıştır. İlaveten, sikkelerin siyasi, içtimai olayların aynası olduğu gerçeğinden hareketle, üzerlerindeki verilerle ulaşılabilinecek bilgilere değinilip, kaynaklar vasitasıyla desteklenmeye çalışılmıştır.

Emevîler Döneminde Abdülmelik b. Mervan'ın saltanatında 697 yılında yaşanan sikke reformu neticesinde basılan ve üzerinde hiçbir figür bulunmayan, İslami ibare ve ayet içerikli yazı kompozisyonlu sikke geleneği, Abbâsîler Döneminde de devam etmiștir. Bununla birlikte Abbâsî Dönemine özgü belirgin farklar da göze çarpmaktadır. Abbâsî Döneminin başlangıç ve ilerleyen zamanlarındaki sikke uygulamaları değişiklik gösterdiğinden, iki dönem halinde ele almak, süreci daha algılanabilir hale getirecektir. Değişim/gelişim seyrini, başlangıcından Halife Me‘mûn'a kadar olan dönem ve ilerleyen yıllarda kimi belirgin yenilikler nedeniyle Halife Me‘mûn'dan itibaren olan dönem olarak incelemek, en azından takibin anlaşılabilirliği bağlamında yanlış olmayacaktır. Ayrıca altın dinar ve gümüş dirhemler üzerindeki yazı kompozisyonları da birbirinin aynı olmayıp bazı değişiklikler göstermektedir.

Günümüze ulaşabilmiş Abbâsî dönemi sikke örnekleri kronolojik olarak incelendiğinde, değişim/gelişim seyri açıkça ortaya konabildiği gibi, sikkelerde rastlanılan ipuçları sayesinde, tarihi bilgilerle de bağlantı kurulabilmektedir. Bu da birer tarihi vesika niteliğindeki sikkelere olan ilgiyi artırmaktadır. Bu anlamda, bilgi teyidinin ötesinde yeni bilgi ve açıklamalara da ulaşılabilmesi daima mümkün olduğundan, konuyla ilgili yapılacak çalışmalar pek çok bakımdan oldukça önem arz etmektedir.

Anahtar Kelimeler: Abbâsîler, Abbâsî Sikkeleri, İslam Sikkeleri.

Abstract: In this study, it was aimed to determine the basic stages of chronological development of the coins belonging to the Abbasid period in terms of their design, composition and practice and consequently to be able to perceive the coin printing process of the relevant period concretely. In addition, considering the fact that the coins reflect political, and social events, the information that can be reached due to the data on the coins is mentioned and

** Dr. Öğr. Üyesi, Uşak Üniversitesi, gunnur.aydogdu@usak.edu.tr 
tried to be supported by sources. Due to the abundance of Islamic coinage, the main sources being referred to in this regard are the examples from Kahramanmaras Museum, as well as the examples in the collections provided in other publications and web sites.

The tradition of the coinage, which was published in the reign of Abdulmelik b. Mervan in 697 during the Umayyad Period as a result of the coinage reform, and which contained Islamic inscription and verse with no figures on them, continued in the Abbasids period as well. Moreover, distinct differences peculiar to the Abbasid period are also striking. Since the coinage practices in the early and late period of Abbasids vary, handling this process in two stages will make it more perceptible. Due to some distinct differences in the following years, examining the process of change / development, in two stages as the period from the beginning to the Caliph Me'mûn, and the period beginning from the Caliph Me'mûn will be more accurate in terms of clarity. In addition, conserning some changes, the compositions of the inscriptions on the golden dinar and silver dirhems are not exactly the same.

When the coinage samples of the Abbasid period which reached to the day are analyzed chronologically, the change / development process can be clearly revealed, and the clues found in the coins can be linked to historical information. This in turn increases the interest in the coins which are historical documents. In this context, since it is always possible to reach new information and explanations, studies to be carried out on this topic is very important in many respects.

Key Words: Abbasids, Abbasid Coins, Islamic Coins.

\section{Giriș}

İslam'ın ilk evrelerinde ticaret piyasasında tedavülde bulunan ve yüksek teveccüh gören Bizans solidusu ve Sasani drahmisi, Emevî Halifesi Abdülmelik b. Mervan Döneminde H. 77 / M. 697 yılında yapılan sikke reformuna kadar yoğunlukla kullanılmıştır. Tamamen yazı kompozisyonundan oluşan ve İslami ibareler içeren yeni sikkeler, siyasi, coğrafi ve ticari alanda yükselişte bulunan yeni dinin mensuplarının ve onların devletinin mesajını tüm dünyaya iletmek, bir anlamda propagandasını yapmak üzere uzun sürecek yolculuğuna başlamıştır. İslami ibare ihtivalı sikkelerin, Emevi Halifesi Ömer b. Abdülaziz Döneminde bazı kimseleri rahatsız ettiği ve bu düşüncelerini halifeye ilettikleri anlaşılmaktadır. Halifeye gelerek, bu dirhemlerin üzerinde Allah'ın ayetlerinin yazdığını; Hıristiyan, Yahudi, cünup ve hayızlı olanların bunları eline aldıklarını ve eğer irade buyurursa bu yazıları sileceklerini ifade etmişlerdir. Halife de onlara, "Rabbimizin birliğini ve Peygamberimizin ismini bizim dışımızdakilere bildirmek isterim" demiştir. ${ }^{1} \mathrm{Bu}$ ifadeden halifenin, sikkeler aracılı̆̆ıyla mesajını vermek arzusunda olduğu açıkça anlaşılabilmektedir.

Sikkelerin basımı bu şekilde -zaman zaman kimi ufak değişikliklerle- devam etmiştir.

Dini açıdan Emevî yönetiminin meşrûiyetini reddederek, Müslümanları yönetme hakkının Peygamber ailesinden olmaları nedeniyle kendilerine ait olduğunu ileri süren Abbâsîler, İslam tarihinde dönüm noktası kabul edilen bir ihtilalle iktidara gelmişlerdir. ${ }^{2}$

Genel anlamda halifelerin mutlak otoritesinin ve siyasi güçlerinin zirvede olduğu Abbâsîler'in erken dönemlerinde, sosyal, siyasi vb. yapıda önemli değişikliklerin olduğu kesindir. ${ }^{3} \mathrm{Bu}$ gibi hususların sikkeler üzerindeki yansımaları daima karşılaşılan bir durum olduğundan, kimi ufak ama belirgin farkların, yeni iktidarın bastırdığı paralarda belirmesi olağandır. Bu bağlamda ilk göze çarpan değişim, arka yüzün yatay yazısında olmuştur: Emevî sikkelerinde İhlas suresinin bir kısmının olduğu ayetlerin yerine, Abbâsî sikkelerinde Hz. Muhammed'in Allah'ın elçisi olduğu vurgusu yerleştirilmiştir.

Pek çok alanda yaşanılan yüksek refah düzeyi ile anılan Halife Hârûnürreşîd Döneminde kendini gösteren güçlü vezirler, adlarını sikkeler üzerinde de duyurmuşlardır. Aslında Abbâsî

\footnotetext{
${ }^{1}$ Takiyuddin Ahmed b. Abdülkadir Makrîzî, Kitâbu'n-Nukûdi'l-Kadîmeti ve'l-İslâmiyye, Konstantiniyye 1298

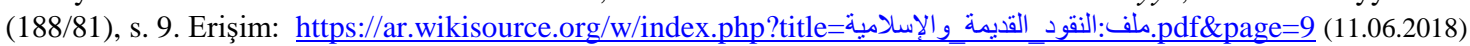

${ }^{2}$ Nahide Bozkurt, Abbasiler, İsam Yayınları, İstanbul 2013, s. 11, 17, 18; İbn Kesîr, El Bidâye ve'n-Nihaye Büyük İslam Tarihi, C. 10, Çev. Mehmet Keskin, Çağrı Yayınları, İstanbul 1995, s. 75-97.

${ }^{3}$ N. Bozkurt, a.g.e., s. 41.
} 
sikkeleri üzerinde, Halife Mehdî dirhemlerinden itibaren halifenin adı ve sonrasında ise başka diğer pek çok isimle karşılaşılmaktadır; oğullar, veliahtlar, vezirler, valiler gibi.

Hârûnürreşîd'in iki oğlu Muhammed Emîn (H. 193/M. 809 - H. 198/M. 813) ve Abdullah Me'mûn (H. 198/M. M. 813 - H. 218/M. 833) arasında yaşanan taht mücadelesi Me'mûn'un lehine sonuçlanmıştır. Bu netice, Me'mûn Döneminde sikkelerin ön yüz kompozisyonuna ilave edilen ikinci yazı kuşağının muhteviyatı nedeniyle, "galibiyet ve tasarım" arasında bağ kurulmak istenmesine neden olmuştur.

Halife Muhammed Râzî Döneminde, baş gösteren merkezi otorite zayıflığını gidermek ve devlet yönetimini kuvvetlendirmek amacıyla, geniş yetkilere sahip "Emîrü'l-Ümerâlık Makamı" tesis edilmiştir. H. 324-447/M. 936-1055 yılları arasında devam eden bu Emîrü'l-Ümerâlık makamının ünlü isimlerinden Beckem, Tüzün ve Nasırüddevle yine Abbâsî sikkelerinde halife adları dişında rastlanılan devlet ricalinden isimlerdir.

H. 334/M. 945 yılında Şii Büveyhîler'in Bağdat'a girmesiyle başlayan Büveyhîler Döneminde, Abbâsî halifeleri hilafet makamının sadece sembolik dini lideri durumundayken, devlet işlerinde söz sahibi Büveyhî emirleri olmuştur. Bu hâkimiyeti sona erdirmek isteyen Abbâsî Halifesi Kâim-Biemrillah'ın, Büyük Selçuklu Sultanı Tuğrul Bey'den yardım istemesi üzerine H. 447/M. 1055 y1lında Bağdat'a girilmiş ve bu kez söz sahibi Selçuklu olmuştur. ${ }^{4}$ Bu tarihi süreç, son dönem Abbâsî halifeleri sikkelerine nadiren rastlanışını doğrudan açıklar.

Moğol Hakanı Hülagü, Abbâsî Halifesi Musta'sım'dan Haşhaşiler'e karşı istediği ordu desteğinin verilmemesi üzerine, H. 656/M. 1258 yılında Bağdat şehrini alarak halifeyi idam ettirmiş ve Abbâsî devletine son vermiştir. ${ }^{5}$

\section{Abbâsîler Dönemi Altın ve Gümüş Sikkeleri}

Abbâsî Döneminde, Emevî Dönemini takiben benzer şekilde altın dinar, gümüş dirhem ve bakır felsler basılmaya devam edilmiştir. Bununla birlikte Abbâsî Dönemine özgü belirgin farklar da göze çarpmaktadır. Abbâsî Döneminin başlangıç ve ilerleyen zamanlarındaki sikke uygulamaları değişiklik gösterdiğinden, iki dönem halinde ele almak, süreci daha algılanabilir hale getirecektir. Değişim/gelişim seyrini, başlangıcından Halife Me'mûn'a kadar olan dönem (H. 132/M. 750 - H. 198/M. 813) ve ilerleyen ylllarda kimi belirgin yenilikler nedeniyle Halife Me'mûn'dan itibaren olan dönem (H. 198/M. 813 - H. 656/M. 1258) olarak incelemek en azından takibin anlaşılabilirliği bağlamında yanlış olmayacaktır.

a. Erken Dönem Abbâsî Sikkeleri (H. 132/M. 750 - H. 198/M. 813 Abbâsî Döneminin başlangıcından Halife Me'mûn Dönemine Kadar)

Günümüze ulaşan örnekler 1şı̆̆ında ${ }^{6}$, Abbâsîler Döneminde altın sikkeler üzerinde görülen kompozisyonun, yazı unsuru ile sınırlı olduğu anlaşılmaktadır. Ön yüzlerde ortada üç satır halinde yatay olarak "Lâ ilâhe illâ Allah Vahdehu Lâ şerîke leh (لا اله الا الله وحده لا شريك لهاله)" ibaresi yer alırken, sikkenin etrafını dolanan yazı kuşağında ise Tevbe suresi 33. ayet; Muhammedün Rasûlullah erselehü bi'l-hüda ve dîn'ül-hakki liyüzhirahu ala'd-dîni küllihi velev kerihe'l-müşrikun (Allah'ın elçisi Muhammed, Allah'a ortak koşanlar hoşlanmasalar bile dini, bütün dinlere üstün kılmak için, (Allah tarafindan) hidayetle ve hak dinle gönderildi) bulunmaktadır. Arka yüzlerde ise, ortada yatay üç satır halinde "Muhammed Rasûl Allah / محمد

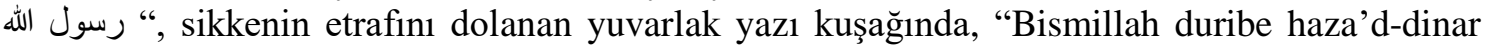
sene... /... "بسم الله ضرب هذا الدينار سنة "kalıb1 ile sikkenin birimi ve basım tarihi yer almaktadır. Erken dönem altın sikkelerinde darp yeri ve halife adına rastlanmamaktadır. (Şekil 1)

\footnotetext{
${ }^{4}$ N. Bozkurt, a.g.e., s. 108, 146.

${ }^{5}$ N. Bozkurt, a.g.e., s. 121-123.

${ }^{6}$ Kahramanmaraş Müzesi Sikke Koleksiyonu, yayınlarda ve web sitelerinde yer alan örnekler incelenmiştir.
} 
Ön Yüz:

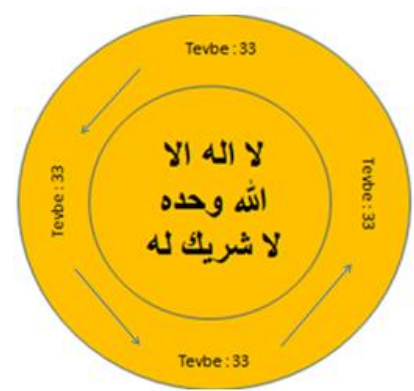

Arka Yüz:

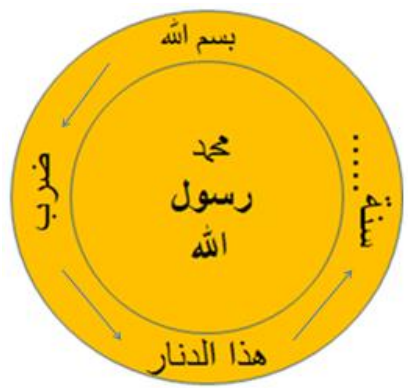

Şekil 1: Erken Dönem Abbâsî Dinarı Temel Yazı Kompozisyonu (Aydoğdu, 2018).

Gümüş sikkelerde, yazı ve geometrik formlarla oluşturulmuş kompozisyonlar dikkati çekmektedir. Gümüş sikkelerde yer alan yazı kalıpları, Abbâsî Döneminin başlarından sonuna kadar kimi farklılık ve çeşitlilikler sergilemektedir. Erken dönemlerde ön yüzde üç satır halinde "Lâ ilâhe illâ Allah Vahdehu Lâ şerîke leh / لا اله الا الله وحده لا شريك له"ibaresi yer alırken, sikkenin etrafinı dolanan yazı kuşağında ise, "Bismillah duribe haza'd-dirhem bi... sene... / "بuم kalıbı ile sikkenin basım yeri ve tarihine ilişkin bilgiler verilmektedir. Ancak halife adına rastlanmamaktadır. Yazı kuşağı üç sıra yuvarlak silme ile çerçevelenmiştir. Dıştaki silme üzerinde, aralarda bazen üç, bazen iki veya birer minik dairelerin yerleştirilmesiyle süsleme oluşturulmuştur. Arka yüzlerde ise, "Muhammed Rasûl Allah" ibaresi yer alırken, sikkenin etrafını dolanan yazı kuşağında Tevbe suresi 33. ayet yer almaktadır. Sikkelerin arka yüzlerinde ortadaki yatay yazılar yuvarlak çerçeve içerisine alınmış ve yazı kuşağından sonra sikke yine dairevi bordürle nihayetlendirilmiştir. (Şekil 2)

Ön Yüz:

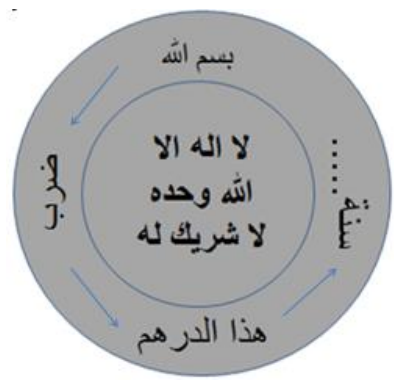

Arka Yüz:

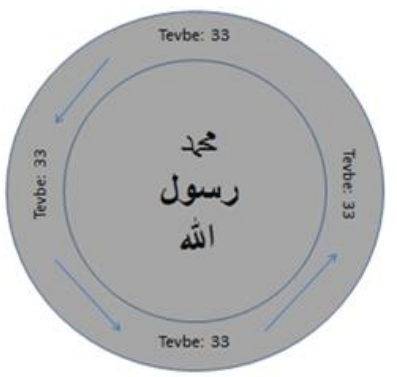

Şekil 2: Erken Dönem Abbâsî Dirhemi Temel Yazı Kompozisyonu (Aydoğdu, 2018).

Gümüş sikkelerin arka yüzlerinde görülen kalıp ibarenin zamanla değiştiği veya ilaveler yapıldığı görülmektedir. Mesela, Halife Mansûr Dönemi (H. 136/M. 754 - H. 158/M. 775) gümüş sikkelerinin arka yüzünde "Mimmâ emera bihi El-Mehdî Muhammed (Halife Mansûr'un oğlunun ad1) bin emîri'l-Mü'minîn / مما امر به المهدى محمد بن امير المومنين"; Mehdî Döneminde (H. 158/M. 775 - H. 170/M. 785), "Muhammed Rasûl Allah Salli Allah Aleyhi ve Sellem elHalîfet'ül-Mehdî محمد رسول الله صلى الله عليه و سلم الخليفة المهدى"; Harun Reşid Döneminde (H. 170/M. 786 - H. 193/M. 809), "Muhammed Rasûl Allah Yezîd / محمد رسول الله يزيد", "Mimma مما امر به الامير الامين محمد / Emera bihi'l-Emîr el-Emîn Muhammed bin emîr el-Mü'minîn Ca'fer “ب “بziları dikkati çeker.

$\mathrm{Bu}$ temel bilgilerin ardından kronolojik olarak sikkeler ve tarihsel olaylarla bağlantıları hususundaki tahlillere bakılabilir. Abbâsîler'in ilk Halifesi Ebu'l-Abbas es-Seffâh Dönemi (H. 132/M. 750 - H. 136/M. 754) sikkelerinde tasarım ve uygulama anlamında herhangi bir değişikliğe gidilmediği ancak, Emevî sikkelerinin arka yüzünde bulunan İhlâs suresi yerine burada kısaca Hz. Muhammed'in Allah'ın elçisi olduğunu belirten "Muhammed Rasûl Allah / (ibaresi uygun görüldüğü izlenmektedir. (Fotoğraf 1) 

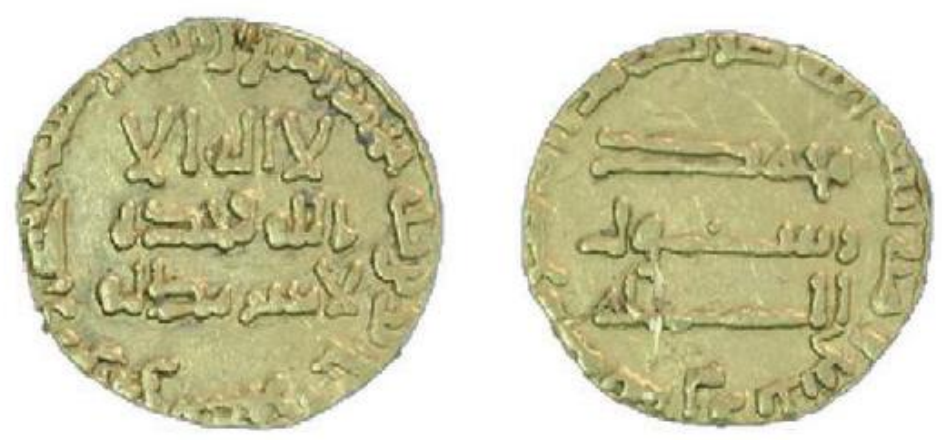

Fotoğraf 1: Ebu'l-Abbas es-Seffâh Dönemine ait H. 135 (M. 752/53) tarihli dinar örneği (Aydoğdu, Bismi’llah duribe haza'd-dinar sene hamse ve selâsîn ve mi'e.

Gümüş sikkelerde ise basım tarihiyle birlikte buna ilaveten basım yerinin de verilmesi önemlidir. (Fotoğraf 2)
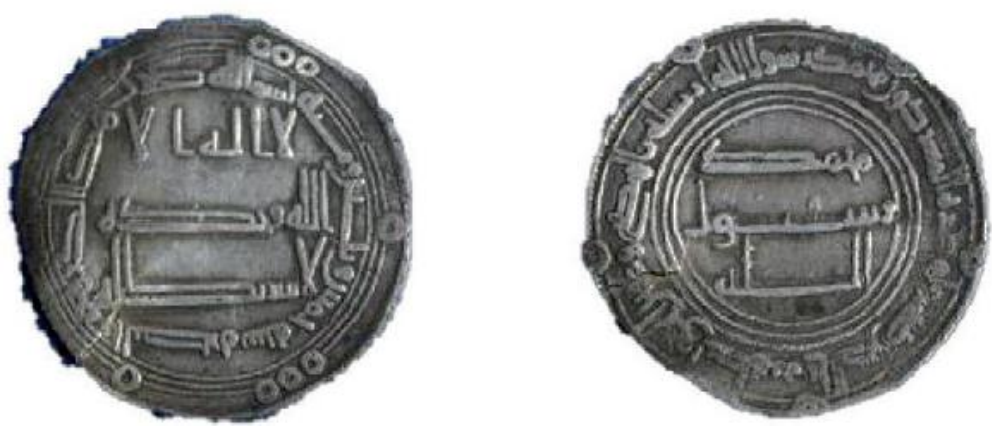

Fotoğraf 2: Ebu'l-Abbas es-Seffâh Dönemine ait H. 135 (M. 752/53) tarihli ve Basra bask1lı dirhem örneği (Aydoğdu, 2015). Bismi'llah duribe haza'd-dirhem bi'l-Basra sene hamse ve selâsîn ve mi'e.

Halife Mansûr Dönemi (H. 136/M. 754 - H. 158/M. 775) sikkelerinde, önceki kompozisyon ve uygulamanın aynı şekilde devam ettiğ $i^{7}$ anlaşılmakla birlikte, özellikle Horasan bölgesinde basılmış, Mehdî adının geçtiği Mansûr Dönemi sikkelerinin bulunduğu belirtilmektedir. ${ }^{8} \mathrm{Bu}$ görüşün dayanağı, Halife Mansûr'un, Alioğulları'na karşı zafer kazanan oğlu Muhammed'in "Mehdî" (kendisine zafer bahşedilen) ünvanı ile taltif edildiği ve veliaht olarak sikkelerde adının geçtiği bilgisidir. ${ }^{9}$ Ancak, İslam tarihi kaynaklarına bakıldığında, Mansûr Dönemi Alioğulları isyanında, mücadele ve galibiyette Mehdî'nin adından ziyade, Halife Mansûr, Abbasîler'in Medine Valisi ve halifenin amcaoğlu olan birlik komutanı İsâ b. Musa'nın etkin rol oynadığı izlenmektedir. Hatta Mehdî'nin, babasının Alioğullarına karşı olan sert tutumunun aksine, onları kazanmayı hedefleyen uzlaşmacı bir tutum sergilediğinden bahsedilmektedir. ${ }^{10}$ Yani adının sikkelerde veliaht olarak yer alması bununla ilgili olmayıp, kanaatimizce Mansûr'un Mehdî'ye olan sevgisi ve resmi veliaht İsâ b. Musa'yı azlederek yerine ssrarla onu veliaht tayin etmek isteği olmalıdır. Çünkü -İbnü'l-Esîr'in detaylıca anlattığı olaya göreMansûr bu uğurda İsâ'ya çeşitli baskılar uygulayarak İsâ'yı feragat ettirmeye, küçültücü hareketlerle yıldırmaya çalışmış ve Mehdî'yi daima öne çıkarma eğiliminde olmuştur. Zaten

\footnotetext{
${ }^{7}$ Dönemin zengin dinar örnekleri için, Kolektif, Altının İktidarı, İktidarın Altınları, Yapı-Kredi Para Koleksiyonu Altın Sikke Sergisi, Editör Oğuz Tekin, Proje Koordinatörü Şennur ŞENTÜRK, YKY, İstanbul 2005 adlı yayının katalog bölümü, s. 306-309.

${ }^{8}$ Heideman bununla ilgili üzerinde "Mehdî” yazan ve H. 146 tarihli bir sikke örneği yayınlamıştır. Stefan Heideman, "Numismatics", The New Cambridge History Of Islam ,Volume 1, The Formation Of The Islamic World, Sixth To Eleventh Centuries, Edited By Chase Robinson, Cambridge University Press, 2010, plate: 16.16.

${ }^{9}$ Heideman, Rey şehrinde H. 145 / M. 762 yılında, tehditkâr Ali taraftarları baskısı ve isyanının olduğu yılda, veliaht Muhammed'in Mehdî ünvanıyla sikkeler üzerinde adının olduğunu ifade etmektedir. S. Heideman, a.g.m., s. 657).

${ }^{10}$ N. Bozkurt, a.g.e., s. 53.
} 
sonunda da, baskılara dayanamayan İsâ, feragat etmiştir. ${ }^{11}$ Halife Mansûr'un sikkelerinde kendi adının geçmemesi, varisiyle birlikte kendi adının bulunmaması veya babası hayatta iken sadece veliaht Mehdî'nin adının bulunması -kendi bölgesinde basılmış olsa da- ayrıca ilginç olup, oğul Mehdî’nin varis olarak benimsetilmesi gayretinin bir sonucu gibi görünmekte ve görüşümüzü desteklemektedir.

Halife Mehdî Dönemi (H. 158/M. 775 - H. 170/M. 785) dinarlarında yine halife adı verilmeyerek daha önceki sikkelerde olduğu gibi Muhammed Rasûl Allah ifadesiyle yetinilmiştir. (Fotoğraf 3)
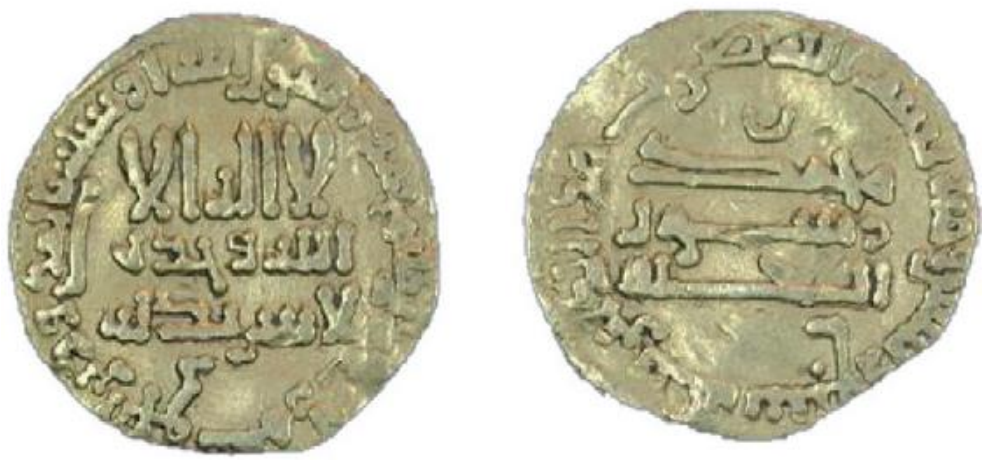

Fotoğraf 3: Halife Mehdî Dönemine ait H. 167 (M. 783/84) tarihli dinar örneği (Aydoğdu, 2015). Bismi'llah duribe haza'd-dinar sene seb'a ve sittîn ve mi'e.

Sikkeler üzerinde halife isminin ilk kez görülmesi, Halife Mehdî’nin "dirhem”lerinden itibaren başlamaktadır. Halife, arka yüzde adını الخليفة المهذى / El-Halîfet’ül-Mehdî şeklinde ünvanıyla birlikte verdirmiştir. Bunun altındaki nokta da yine ilk olup dikkat çekicidir ${ }^{12}$ (Fotoğraf 4). Bununla ilgili olarak, "Mehdî Muhammed b. Ca'fer o yıl içerisinde (H.158), üzerinde noktalar bulunan yuvarlak sikkeler bastırmıştır", denilmektedir. ${ }^{13}$
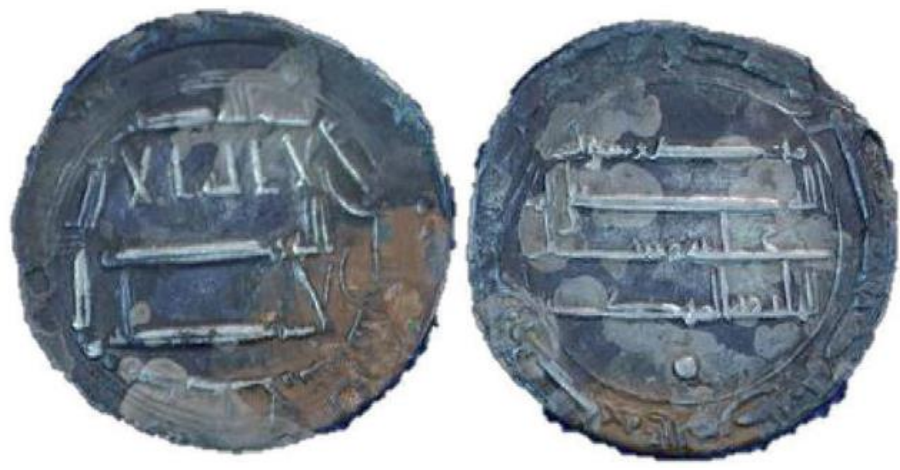

Fotoğraf 4: $\quad$ Halife Mehdî Dönemine ait H. 162 (M. 778/79) tarihli dirhem örneği (Aydoğdu, 2015). Bismi'llah duribe haza'd-dirhem biMedînetü's-Selâm sene isneteyn ve sittîn ve mi'e.

Halife Hârûnürreşîd Döneminde (H. 170/M. 786 - H. 193/M. 809), gerek dinar gerek dirhem basımının yoğun olduğu, günümüze ulaşan örneklerin bolluğundan anlaşılmaktadır. Bu

\footnotetext{
${ }^{11}$ İbnü'l-Esir, El Kamil Fi 't-Tarih Tercümesi, C. 5, Bahar Yayınları, İstanbul 1986, s. 466-469.

12 Halife Mehdî adına kestirilmiş bir başka sikke örneği üzerinde ise, nokta unsuru yan yana iki tane olarak uygulanmış ve en alt satırda da بخ yazılmıştır. Bunun ne anlama geldiği, hangi duruma işaret ettiği ilginç bir araştırma konusu olacaktır. İlgili sikke örneklerinin fotoğrafı ve detaylı anlatımı için Günnur Aydoğdu, İslam Sikkeleri Kahramanmaraş Müzesi Ölçeğinde, Türkiye Alim Yayınları, Saarbrücken 2015, s. 69-72.

13 Takiyuddin Ahmed b. Abdülkadir Makrîzî, Kitâbu'n-Nukûdi'l-Kadîmeti ve'l-İslâmiyye, Konstantiniyye 1298 (188/81), s. 10. Erişim: https://ar.wikisource.org/w/index.php?title="ملف:النقود القديمة و الإسلامية'pdf\&page=9 (11.06.2018)
} 
durumun, dönemin ekonomisinin ulaştığı seviye ile yakından ilișkili olduğu açıktır. Örneklerde halifenin ad1 verilmemiştir. Ancak arka yüzde الخليفة / el-Halîfe (ya da l'il-halîfe) ifadesi bulunanların (Fotoğraf 5) yanısıra, kimi örneklerde çeşitli isimlerin varlığı dikkati çekmektedir. Bunlardan en yaygın olanı Ca'fer olup, Ali, Musa, İbrahim, Ömer diğer isimlerdir. ${ }^{14}$
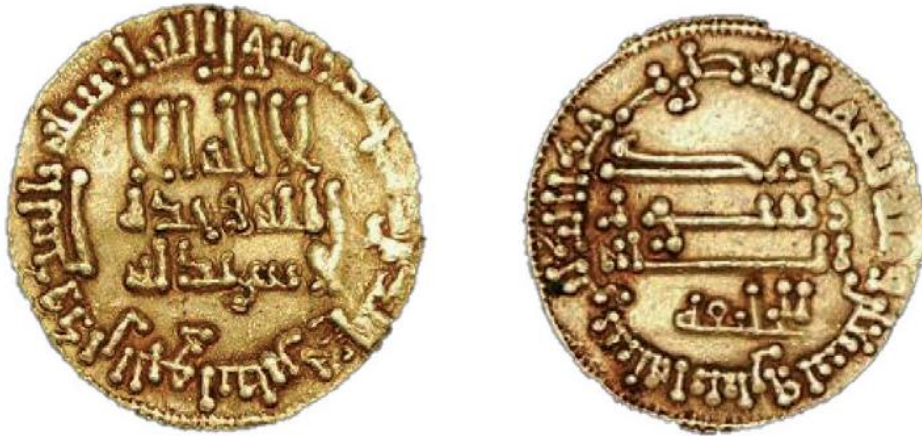

Fotoğraf 5: Halife Hârûnürreşîd Dönemine ait H. 192 (M. 807/08) tarihli dinar örneği (Aydoğdu, 2015). Bismillâh duribe haze'd-dinar sene isneteyn ve tis'în ve mi'e.

Dirhem örneklerinde yine vezir veya o bölgeyi yöneten vali adı yer alabilmektedir. ${ }^{15}$ Atom Damalı bu uygulamanın H.145 (M. 762/63)'den sonra görülmeye başlandığını bildirmektedir. ${ }^{16}$ Fotoğraf 6'da sikkenin arka yüzünde "Vav / Muhammed Rasûl Allah / Mimma Emera bihi'lEmîr el-Emîn / Muhammed bin emîr el-Mü'minîn / Ca'fer" yazısında adı geçen Ca'fer, Hârûnürreşîd'in veziri Fârisî asıllı Ca'fer el-Bermekîi ${ }^{17}$ olmalıdır. Hârûnürreşîd darphane nezareti işlerini veziri Ca'fer'e havale etmiş ${ }^{18}$, o da sikkelere kendi ismini koydurmuştur. ${ }^{19}$ Makrîzî'ye göre, darphanenin idaresi ilk defa halifenin dişında birisine verilmiş ve bu kimsenin (Ca'fer) ismi de sikkede yer almıştır. Bu, halifenin Ca'fer'e duyduğu sevgi ve güvenin bir ișaretidir. $^{20}$

\footnotetext{
${ }^{14} \mathrm{Bu}$ isimlerin geçtiği dinar örnekleri için Kolektif, Altının İktidarı, İktidarın Altınları, Yapı-Kredi Para Koleksiyonu Altın Sikke Sergisi, Editör Oğuz Tekin, Proje Koordinatörü Şennur ŞENTÜRK, YKY, İstanbul 2005 adlı yayının katalog bölümü, s. 311-313.

15 Mesela, Halife Hârûnürreşîd Dönemine ait kimi dirhem örneklerinin arka yüzünde rastlanılan "Yezîd" ismi, dönemin bölge valisinin adıdır. Örnek ve detaylı bilgisi için G. Aydoğdu, a.g.e., s. 71-72.

${ }^{16}$ Atom Damalı, 150 Devlet 1500 Sultan Íslam Sikkeleri, Nilüfer Damalı Eğitim Kültür ve Çevre Vakfı Yayınları, İstanbul 2001, s. 31.

${ }^{17}$ Hârûnürreşîd halife olunca, Halid b. Bermekî’nin oğlu Yahya b. Halid'i baş vezir tayin etmiş; mühür dairesinin yöneticiliği de zaman zaman onun oğulları Fazl ve Ca'fer'e verilmiştir. Berid teşkilatı, "darphane" ve tıraz atölyeleri Ca'fer'e bağlanmış, devletin mühim kademelerinde görev verilmiş, Halife tarafından bizzat teveccüh görmüştür. Halife ile oldukça yakın olan Bermekîler, çeşitli görüşler olmakla birlikte kesin olarak bilinemeyen sebeplerle, servetlerine el konularak bertaraf edilmiş ve Ca'fer halifenin emriyle 186/802 yılında idam edilmiştir N. Bozkurt, a.g.e., s. 55; Hakkı Dursun Yıldız, "Bermekîler", Türkiye Diyanet Vakfi İslam Ansiklopedisi, C. 5, İstanbul 1992, s. 518. Hârûnürreşîd'in, Yahya'nın oğulları Ca' fer ve Fazl'1, tahta çıktığı aynı gün vezirliğe getirdiği ifade edilmektedir. Andre Clot, Harun Reşid ve Abbasiler Dönemi, Çev. Nedim Demirtaş, Tarih Vakfı Yurt Yayınları, İstanbul 2007, s. 32.

${ }^{18}$ N. Bozkurt, a.g.e., s. 55; İbrahim Artuk, Abbasiler Devrinde Sikke, Ayrıbasım (Belleten C. XXIV, S. 93, 1960'dan ayribasım), Ankara1960, s. 26.

${ }^{19}$ Makrîzî, a.g.e., s. 10; İ. Artuk, a.g.e., s. 26.

${ }^{20}$ H. D. Yıldız, "Bermekîler", s. 519
} 


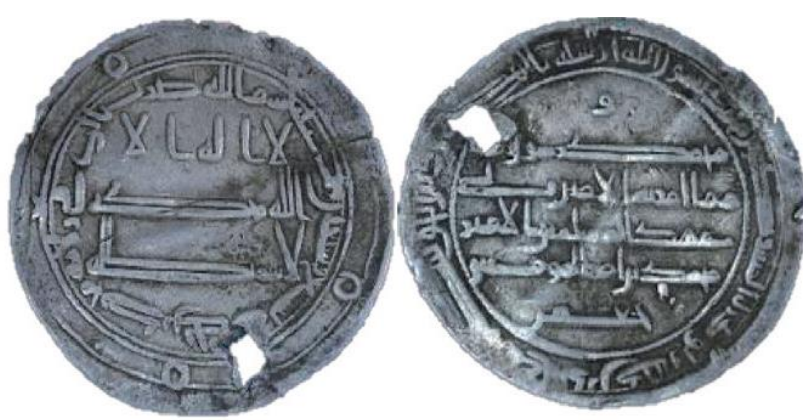

Fotoğraf 6: Halife Hârûnürreşîd Dönemine ait H. 179 (M. 795/96) tarihli dirhem örneği (Aydoğdu, 2015). Bismi'llah duribe bi’l-Rey fî̀ Vilâyet-i Muhammediye Rey sene tis'a ve seb'în ve mi'e.

Üzerinde isim zikredilen örneklerin dişında sadece محمد رسول الله ifadesiyle yetinilmiş örnekler de mevcuttur (Fotoğraf 7).
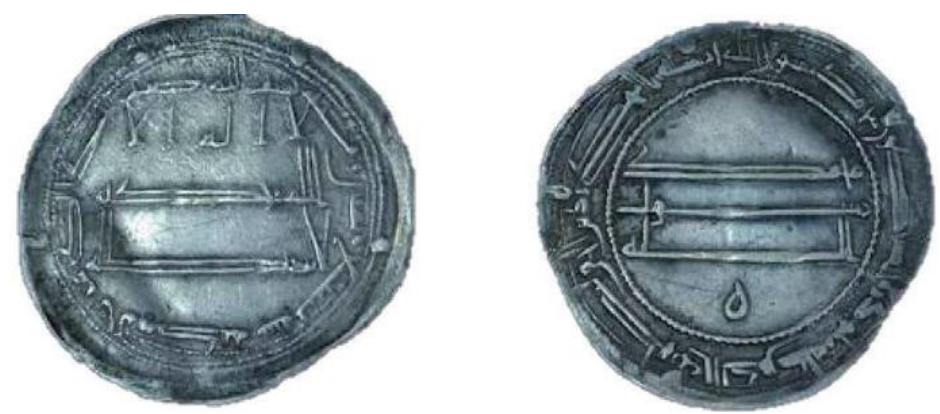

Fotoğraf 7: Halife Hârûnürreşîd Dönemine ait H. 189 (M. 804/05) tarihli dirhem örneği (Aydoğdu, 2015). Bismi'llah duribe hâzad-dirhem bi’l-Muhammediye sene tis'a ve semenîn ve mi'e.

Halife Emîn Döneminde (H. 193/M. 809 -H. 198/M. 813), dinarlar üzerinde halife ismine rastlanılmaktadır (Fotoğraf 8). El-Halife Emîn yazanların yanısıra, el-Halife - el-İmam yazan dinar örnekleri de mevcuttur (Fotoğraf 9).

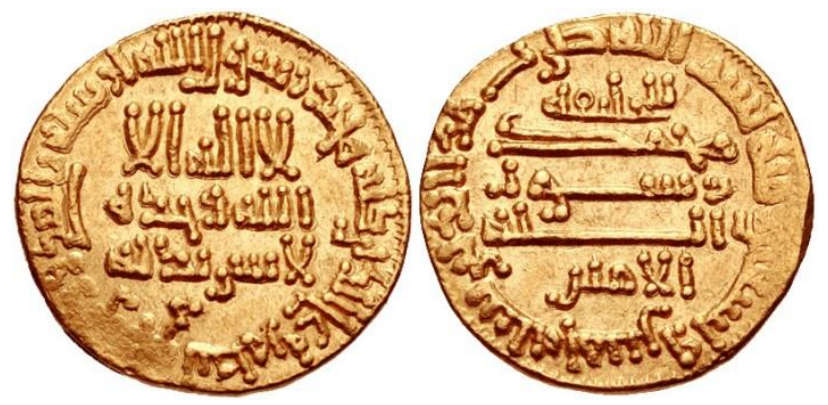

Fotoğraf 8: Halife Emîn Dönemine ait H. 195 (M. 810/1) tarihli dinar örneği. ${ }^{21}$

${ }^{21}$ Coin Archives. 08.06.2018.

Erişim: https://www.coinarchives.com/6c178743d1e3cb8cd1c358fa7ef37fdb/img/cng/e/273/image00519.jpg 


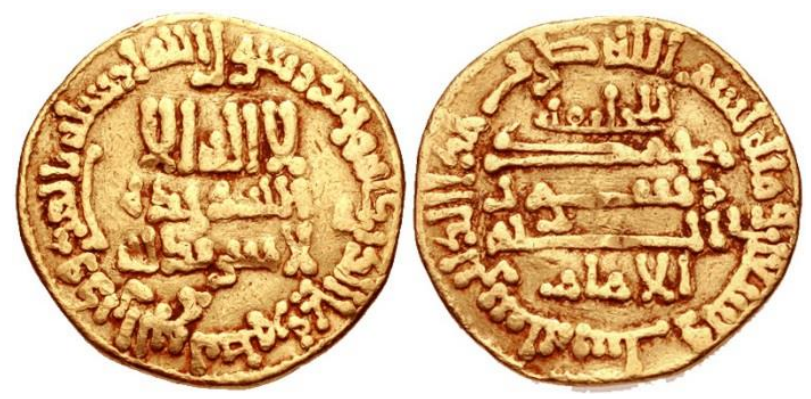

Fotoğraf 9: Halife Emîn Dönemine ait H. 196 (M. 811/12) tarihli dinar örneği. ${ }^{22}$

b. İlerleyen Yıllardaki Abbâsî Sikkeleri (H. 198/M. 813 - H. 656/M. 1258 Halife Me'mûn döneminden itibaren Abbâsî Döneminin sonuna kadar)

İlerleyen dönemlerdeki altın dinarlarda çeşitli farklılıklar göze çarpmaktadır. Halife Me'mûn'un saltanatının (H. 198/M. 813 - H. 218/M. 833) ilerleyen yıllarında, sikkeler üzerinde yeni bir uygulamayla karşılaşılmaktadır. Genel itibariyle, altın sikkelerin ön yüzlerinde yine ortada üç satır halinde yatay olarak "Lâ ilâhe illâ Allah Vahdehu Lâ şerîke leh / للا اله الا الله وحده لا شريك له ibaresi yer alırken, sikkenin etrafını dolanan yuvarlak yazı kuşağının çift sıra halinde olduğu, ikinci bir yazı kuşağının ilave edildiği dikkati çekmektedir. İçteki yazı kuşağında, daha önceki dönemlerde arka yüzde bulunan tarih bildirir yazılar bu kez ön yüzde ve darp yeri de verilmiş olarak karşımıza çıkmaktadır. Dıştaki yazı kuşağında ise, Rum suresi 4-5. ayetler "Lillâhi'lemru min kablü ve min ba'dü ve yevmeizin yefrahu'l-mu'minun, binasrillah (Önce de, sonra da emir Allah'ındır. O gün Allah'ın zafer vermesiyle mü'minler sevinecektir: لله الامرمن قبل و yer almaktadır. (Şekil 3)

Arka yüzlerde ise ortada beş satır halinde yatay olarak "Lillah Muhammed Rasûl Allah ve dönemin halifesinin adı bulunmaktadır. Sikkenin etrafını dolanan yuvarlak yazı kuşağında ise, daha erken dönemlerde ön yüzde bulunan Tevbe suresi 33. ayet yer almaktadır. İlerleyen dönemlerde halife adının ve darp yerinin altın dinarlarda yer alması, önemli bir fark olarak belirmektedir. (Şekil 3)

Ön Yüz:

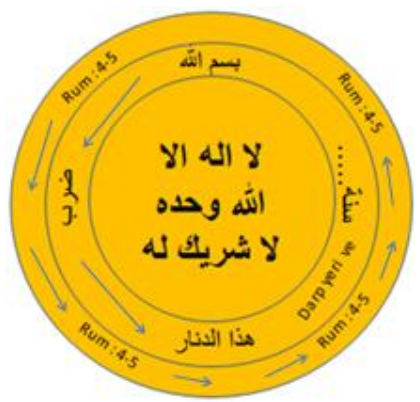

Arka Yüz:

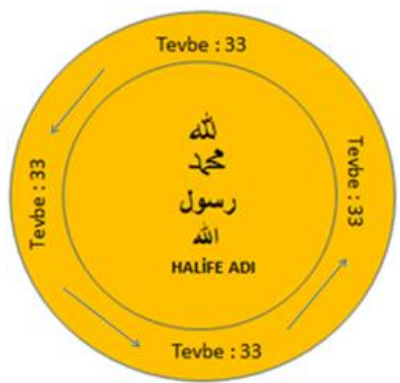

Şekil 3: Halife Me'mûn Döneminden itibaren Abbâsî Dinarı Temel Yazı Kompozisyonu (Aydoğdu, 2018).

İlerleyen yıllardaki gümüş dirhemlerde de yine ikinci yazı kuşağının yer aldığı örnekler bulunduğu gibi tek yazı kuşaklı sikke örnekleri de mevcuttur.

Halife Me'mûn Dönemi (H. 198/M. 813 - H. 218/M. 833) dinar ve dirhemlerinin ön yüz yazı kompozisyonuna ilave edilen ikinci yazı kuşağı ve muhteviyatının, Halife Me'mûn'un

\footnotetext{
${ }^{22}$ Coin Archives. 08.06.2018.

Erişim: https://www.coinarchives.com/16e760335f8c31f5321e68885554f258/img/cng/e/273/image00520.jpg
} 
kardeşiyle olan iç savaşta kendisinin galip gelmesi üzerine, zaferini duyurma ve doğruluğunun Kur'an'a dayandırılması isteğinden kaynaklandığ 1 yolunda anlatımlara rastlanılmaktadır ${ }^{23}$ (Fotoğraf 10-11). Ancak bu konuda, Me'mûn'un halifelik makamına oturması (M. 813) ile bu şekilde tasarımlanan sikkelerin basım tarihleri (eldeki örnekler M. 824) arasında zaman farki olması tereddüte neden olmaktadır. Bu konunun açıklığa kavuşması çok daha fazla sikke örneğinin incelenmesi ve halifeliğinin ilk yıllarından itibaren söz konusu sikkelerin bulunması durumunda mümkün olabilecektir.

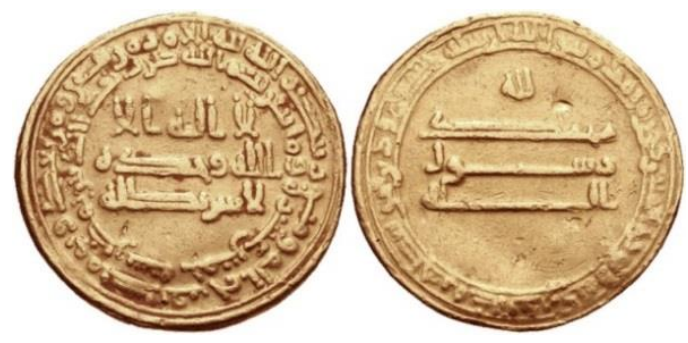

Fotoğraf 10 Me'mun Dönemi dinar örneği ${ }^{24}$
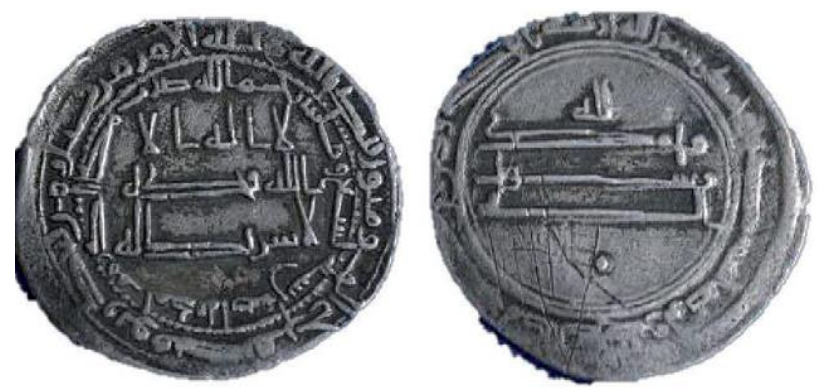

Fotoğraf 11: Me'mun Dönemi H. 209 (M. 824/25) tarihli ve Medineti Isbahan (Isfahan) bask1lı dirhem örneği (Aydoğdu, 2015).

Ancak çift yazı kuşağı ihtiva eden örneklerin yanı sıra hala tek yazı kuşaklı örneklerin mevcudiyeti de günümüze gelen örneklerden bilinmektedir. (Fotoğraf 12)

Yine Halife Me'mûn dönemiyle birlikte sikkelerde gerçekleşen bir diğer yenilik ise, altın dinarlarda darphane isminin verilmeye başlanmasıdır. (Fotoğraf 12 ' de ön yüz yatay yazı sıralarının alt kısmında "Irak" basım yeri olarak verilmiştir).
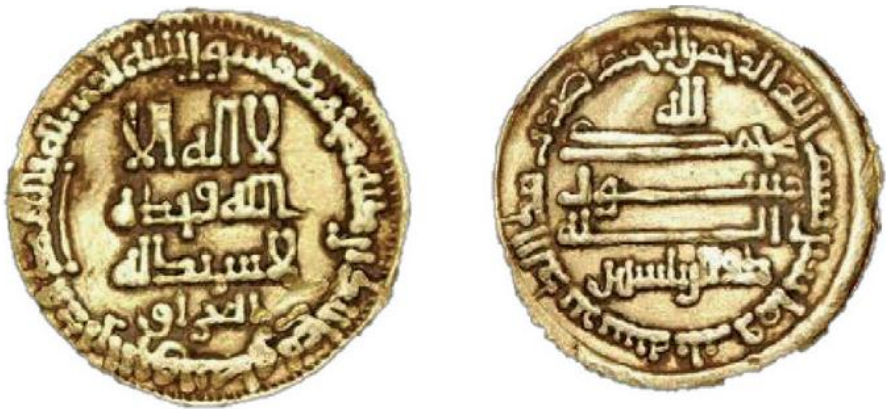

Fotoğraf 12: Halife Me'mûn Dönemine ait Irak baskılı ve H.203 (M. 818/19) tarihli dinar örneği (Aydoğdu, 2015). بسم الله الرحمن الرحيم ضرب هذا الدنار سنة ثلث و ماتين : Bismillâh'i-rrahmân'i-rrahîm duribe haze'd-dinar sene selase ve mieteyn.

${ }^{23}$ Jere L. Bacharach, "Misır ve Suriye İslami Sikkelerini Okumak", Altının İktidarı, İktidarın Altınlarl, Yapı-Kredi Para Koleksiyonu Altın Sikke Sergisi, YKY, İstanbul 2005, s. 73

${ }^{24} 5.6 .2018$. Erişim: https://tr.wikipedia.org/wiki/Mem\%C3\%BBn\#/media/File:Coin_of_the_Abbasid_Caliph_alMa\%27mun.jpg 
Dinarlar üzerinde halife adı yerine vezir ad1 yine görülmektedir. Fotoğraf 12 'deki dinar örneğinin arka yüzünün alt satırında "zü'r-Riyâseteyn / ذو الرياستين", Halife Me'mûn'un veziri Fazl/Fadl b. Sehl'in bizzat halife tarafından verilmiş ünvanıdır. ${ }^{25}$ Anlaşılan o ki, geniş yetkileri elinde bulunduran Fazl b. Sehl, aldığ bu ünvanı dönemin dinarları üzerinde duyurmuştur. ${ }^{26}$

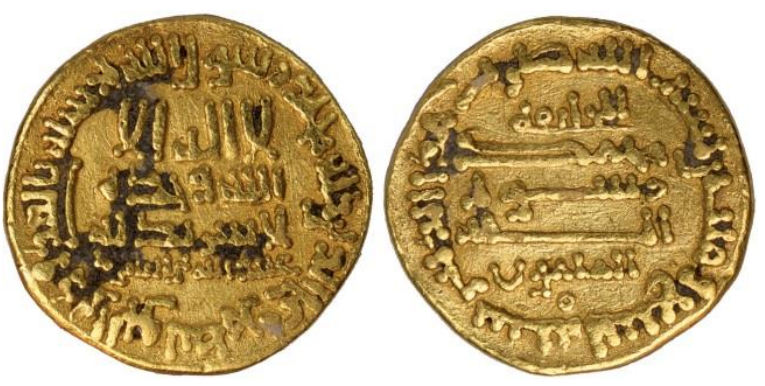

Fotoğraf 13: Halife Me'mûn Dönemine ait H. 209 tarihli dinar örneği ${ }^{27}$

Muktedir ve Râzî Döneminde, Mu'temid ve Mütevekkil sikkelerinde olduğu gibi, ön yüzünde halifelerin "veliahtının", arka yüzde "halifenin kendi adının" verildiği görülmektedir (Fotoğraf $14-17)$.
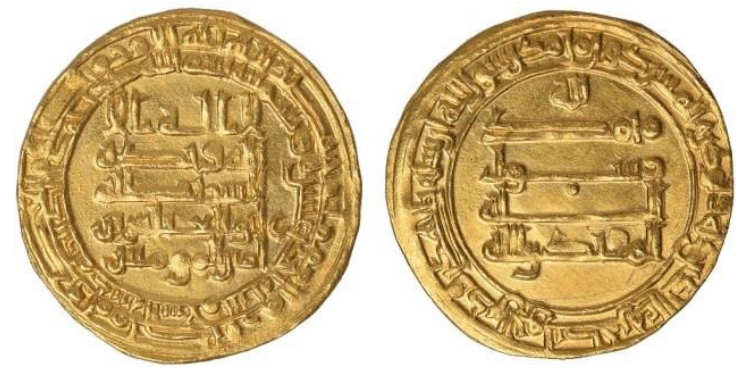

Fotoğraf 14: Halife Muktedir Dönemine ait H. 311 tarihli ve Medinetü’s-Selam (Bağdat) baskılı dinar. ${ }^{28}$
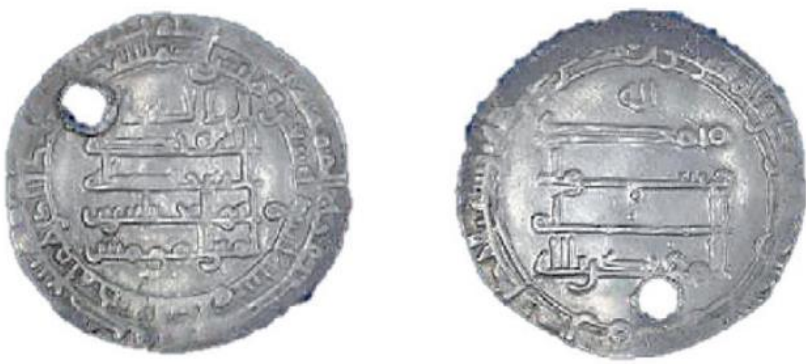

${ }^{25}$ Sonradan Müslüman olmuş İran asıllı Zerdüştî bir babanın oğlu olan, yetenekleri ve Farsça bilgisiyle baş vezir Yahya el-Bermekî’nin dikkatini çeken Fazl b. Sehl, vezir Ca'fer b. Yahya Bermekî ile yakın temaslarda bulunmuş ve onun vasıtasıyla Halife Me'mun'un huzuruna çıkmıştır. Zamanla Halifenin teveccühünü kazanmış; Emîn ile Me'mun arasındaki mücadelede Me'mun'un tarafını turtarak halifelik için teșvik etmiş ve destek olmuștur. Me'mun başarıya ulaşıp halifeliğini ilan edince, Fazl'ı mükâfatlandırmak üzere payesini yükseltmiş ve onu "zü'r-Riyâseteyn" ünvanıyla vezirliğe atamıștır. "Harp ve Kalem İşleri Başkanlığı" manasına gelen zü'r-Riyâseteyn ünvanı, hem askeri hem idari yetkilere sahip olduğunun açık bir ifadesidir. Hatîb el-Bağdâdî (Ebu Bekir Ahmed b. Ali b. Sabit), Târîhu Medîneti's-Selâm ve Ahbâru Muhaddisihâ ve Zikru Kuttâniha el-Ulemâi min Gayri Ehlihâ ve Vâridihâ, (Thk. Beşşâr 'Avvâd Ma'rûf), C. 14, Beyrut 2001(1422), s. 298-303; İbnü'l-Esir, El Kamil Fi't-Tarih Tercümesi, C. 6, Bahar Yayınları, İstanbul 1986, s. 223-226; Hakk1 Dursun Yıldız, "Fazl b. Sehl”, Türkiye Diyanet Vakfi Isslam Ansiklopedisi, C. 12, İstanbul 1995, s. 275-76; Mesut Can, Fazl Bin Sehl'in Hayatı Ve Sahsiyeti, Yayımlanmamıș Yüksek Lisans Tezi, Selçuk Üniversitesi, Sosyal Bilimler Enstitüsü, Konya 2010, s. 27.

${ }^{26}$ Bağdat'ın ele geçirilip Halife Emîn'in öldürülmesinden ve Fazl'ın kardeşi Hasen b. Sehl'in Irak'ın idaresini ele almasından sonra (M. 813) bu paralar tüm ülkede tedavüle çıkmıştır. H. D. Yıldız, "Fazl...”, s. 276.

${ }^{27}$ Coin Archives. 08.06.2018. Erişim:

https://www.coinarchives.com/3c5468f5ebfb7995897f55be5f8c18f7/img/baldwinsofstjamess/018/image00043.jpg

${ }^{28}$ Coin Archives. 08.06.2018. Erişim:

https://www.coinarchives.com/3c5468f5ebfb7995897f55be5f8c18f7/img/baldwinsofstjamess/018/image00043.jpg 
Fotoğraf 15: Halife Muktedir Dönemine ait H. 299 (M. 911/12) tarihli dirhem (Aydoğdu, 2015). Bismi'llah duribe haza'd-dirhem biMedinetü's-Selam sene tis'a ve tis'în ve mieteyn"
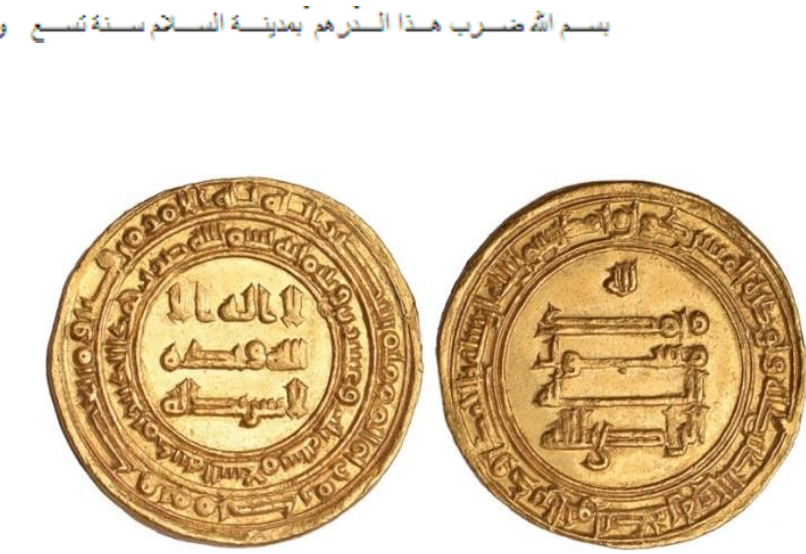

Fotoğraf 16: Halife Râzî Dönemine ait H. 323 tarihli ve Medinetü’s-Selam (Bağdat) baskı1lı dinar. ${ }^{29}$
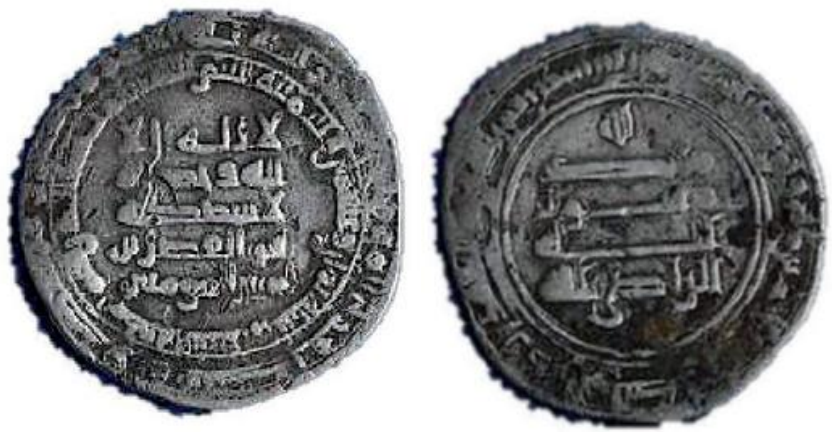

Fotoğraf 17: Halife Râzî Dönemine ait H.328 (M. 939/40) tarihli ve Medinetü's-Selam (Bağdat) baskı1lı dirhem (Aydoğdu, 2015). "Bismi'llah duribe haza'd-dirhem biMedînet es-Selâm sene seman ve '1şrîn ve selâsemi'e" بسم الله ضرب هذا الدر هم بمدينة السلام سنة ثمان و عشرين و ثلث مائة

Halife Râzî Döneminde, kimi örneklerde ise, halifenin adıyla birlikte Emîru'l-Umera ${ }^{30}$ makamındaki isimlere rastlanılmaktadır. Emirler emiri, komutanların komutanı ya da başkomutan anlamına gelen yönetim ve askerlik terimi olan "Emîru'l-Umeralık", ilk olarak Halife Râzî tarafindan, devlet ricali arasındaki rekabetin halifeliği yıpratması üzerine ve bu duruma son vermek maksadiyla makam olarak tesis edilmiştir (H. 324/M. 936). İlk Emîru'lUmera Türk asıllı İbn Râik el-Hazari olup, ondan sonra gelen diğer üç Türk Emîru'l-Umera Beckem, Tüzün ve İbn Şirzad bu görevi ifa etmiş ve bir müddet hilafet merkezini yönetmişlerdir. Musul Hamdânî hükümdarlarından Nasırüddevle de bu görevi bir süre yürütmüştür. ${ }^{31}$ Bunlardan Beckem, Tüzün ve Nasırüddevle adı sikkeler üzerinde yer almıştır.

${ }^{29}$ Coin Archives. 08.06.2018.

Erişim: https://www.coinarchives.com/3f9607d3192a92ad6f280c3be7832a0e/img/stjames/038/image00112.jpg

30 Emîru'l-Umeralar Dönemi (H. 324-447/M. 936-1055): Halife Muhammed Râzî, halifelik makamına geldiğinde, merkezi hükümetin uzak eyaletlerdeki otoritesi kaybolduğundan siyasi çözülmeler başlamıştı. Vezirlerin yönetimde aciz kaldığını ve kontrolün sağlanamadığını düşünen halife, çözüm olarak Emîru'l-Umeralık makamını tesis etmiştir. Oldukça geniş yetkilerin verildiği Emîru'l-Umeralık makamı, protokolde halifeden sonra gelmiştir. N. Bozkurt, a.g.e., s. 105-106.

${ }^{31}$ Ahmet Ağırakça, "Emirul-Umera Ebu'l-Hüseyin Beckem Et-Türki”, MUFEF, Prof. Hakkı Dursun Yıldız Armağanı, Ankara 1995, s.48-63; Ahmet Ağırakça, Ebu Bekir Muhammed İbn Raik ve Emîru'l-Umeralığl, İstanbul 1994, (İstanbul Üniversitesi Edebiyat Fakültesi Tarih Dergisi 1984-94'den Ayrı Basım.); Hakkı Dursun Y1ldız, "Emirul Umera”, Türkiye Diyanet Vakfi İslam Ansiklopedisi, C. 11, İstanbul 1994, s. 158-159. 
(Fotoğraf 18) Emîru'l-Umera adının geçtiği sikkelerde, ön yüzde sikkeyi kestiren Emîru'lUmera adı, arka yüzde dönemin halifesinin adı bulunmaktadır.
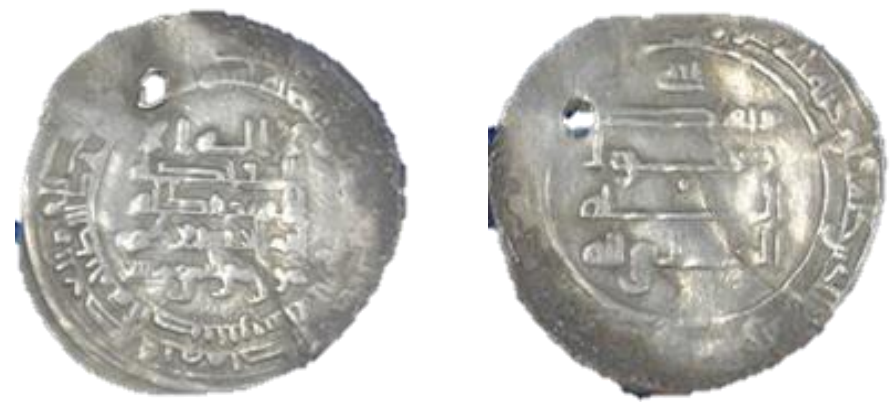

Fotoğraf 18: Abbâsî Emîru'l-Umerası Ebu'l Hüseyin Beckem adının geçtiği dirhem örneği (Aydoğdu, 2015). ("Lâ ilâhe illâ / Allah vahdehu / Lâ şerîke leh / Ebu'l-Hüseyin Beckem / Mevla Emîr el-mü'ninîn).

Son dönem Abbâsî halifelerine ait sikkelere nadiren rastlanılmaktadır. Bu konuda Atom Damalı, H. 334 (M. 946)'da Abbâsî halifelerinin devlet yönetimindeki güçlerini kaybedip, yalnızca dini lider olarak Medinetü's-Selâm'da yaşamaya başlamalarından sonra, hemen hemen hiçbir halifenin sikke bastırmadığı; ancak zaman zaman Abbâsîleri yöneten devletlere karşı isyan eden halifelerin kendi adlarına sikke bastırabildikleri bilgisini vermektedir. ${ }^{32}$

\section{Sonuç}

Doğru ve nitelikli okuma yapılabildiğinde, sikkelerin ekonomik, tarihi, içtimai, siyasi gerçeklere 1şık tutabildiği artık bilinen bir gerçektir. Bu husus, İslam sikkelerinin -antik dönem sikkelerine nispetle- kendisinden esirgenen ilgiyi hak ettiği şekilde yeniden kazanmasında başlıca etken olmuştur.

Aynı durum Abbâsî Dönemi sikkeleri için de söz konusu olup, kaynakları teyid ederek tereddütlü konuları destekleyen ve yeni fikirler veren sikke örnekleri ve onların muhteviyatları, araştırmaların daha ileriye götürülmesini teşvik etmektedir.

Emevî Dönemini takiben benzer şekilde altın dinar ve gümüş dirhem basımına devam edildiği Abbâsî döneminde, gelişen ve değişen içtimai ve siyasi durumlar neticesinde kimi farklılıklar sikkeler üzerinde açıkça izlenmektedir. Emevî sikkelerinin arka yüzünde bulunan İhlâs suresinin bir kısmı yerine, burada kısaca Hz. Muhammed'in Allah'ın elçisi olduğunu belirten " محد رسول الله" vurgusu, Abbâsîler'in dini bakımdan kendilerinden olmayanlara vermek istediği belirgin bir mesaj niteliğindedir.

Halifenin adının -dolayısıyla resmi yöneticinin, onun güç ve iktidarının- sikkeler aracılığıyla ulaşabildiği her bölgeye duyurulmasının, Halife Mehdî’nin dirhemleriyle gelenek haline gelmeye başladığı izlenmektedir. Fakat Abbasi sikkelerinde karşılaşılan, halifelerin ve varislerinin dışında ve sıradan olmadığı açık olan isimler, durumu karmaşık ve açıklanmaya muhtaç hale getirdiğinden, yine tarihe başvurma zorunluluğu doğmaktadır. Ortaya çıan bilgiler oldukça ilgi çekicidir: valiler, vezirler, emîru'l-umeralar gibi. Bunlardan özellikle, üzerinde zü'rRiyâseteyn / ذو الرياستنين lakabı/ünvanı bulunan dinarlar, Hatîb el-Bağdâdî, İbnü’l-Esîr'in eserleri gibi ilk elden kaynaklarda genişçe bahsedilen siyasi nitelikli bir olayın, tarih de veren teyidi ve açıklaması durumundadır.

İslam sikke tarihindeki -Emevî Halifesi Abdülmelik bin Mervan'ın sikke reformundan sonraikinci köklü dönüm noktası olarak nitelendirilen yenilik, Abbâsî Halifesi Me'mûn döneminin ilerleyen yıllarındaki sikkelerinde görülmektedir. Bu önemsenen ve daha sonra da devam eden yenilik, ön yüzdeki yazı kuşağının etrafına ikinci bir yazı kuşağının eklenmesidir. Sikkelerin ön yüz kompozisyonuna ilave edilen ikinci yazı kuşağındaki ayetin muhteviyatı, Emîn ve Me'mûn

${ }^{32}$ A. Damal1, a.g.e., s.32, 33. 
arasında yaşanan mücadele sonrasında “Me'mûn'un, zaferini duyurma, doğruluğunu da Kur'an'a dayandırma isteği” şeklinde yorumlanmış; bu tarihi olay ile sikkedeki ayet ilavesi arasında bağ kurulmak istenmiştir. Ancak, Me'mûn'un halifelik makamına oturması (M. 813) ile bu şekilde tasarımlanan sikkelerin basım tarihleri (eldeki örnekler M. 824) arasında zaman fark1 olması, bu yorumdaki ihtimalin kuvvetlenmesi için çok daha fazla sikke örneğinin incelenmesini gerektirmektedir. Durumun açıklığa kavuşması, Me'mûn'un halifeliğinin ilk yıllarından itibaren söz konusu sikkelerin varlığı durumunda mümkün olabilecektir.

Netice itibariyle, sikke seyir çizgisi ve ortaya çıkan bilgiler, sikkelerle ilgili nitelikli çalışmalar yapıldıkça çeşitli bilim alanlarında aydınlatıcı verilere ve ilginç sonuçlara ulaşılacağının bir göstergesi durumundadır.

\section{Kaynakça}

Ağırakça, Ahmet, Abbâsî Devri Türk Kumandanlarından Emîru'l-Umera Tüzün, TTK Basımevi, Ankara 1994.

Ağırakça, Ahmet, Ebu Bekir Muhammed İbn Râik ve Emîru'l-Umeralı̆̆g, Edebiyat Fakültesi Basımevi, (İstanbul Üniversitesi Edebiyat Fakültesi Tarih Dergisi sayı: 35, 19844-94'den Ayrı Basım) İstanbul 1994.

Ağırakça, Ahmet, "Emirul-Umera Ebu'l-Hüseyin Beckem Et-Türki”, MUFEF, Prof. Hakkı Dursun Ylldız Armağanı, Ankara 1995, ss.48-63.

Artuk, İbrahim, Abbâsîler Devrinde Sikke, Ayrıbasım (Belleten C. XXIV, S. 93, 1960'dan ayrıbasım), Ankara1960.

Aydoğdu, Günnur, İslam Sikkeleri Kahramanmaraş Müzesi Ölçeğinde, Türkiye Alim Yayınları, Saarbrücken 2015.

Bacharach, Jere L., "Misır ve Suriye İslami Sikkelerini Okumak", Altının İktidarı, İktidarın Altınları, Yapı-Kredi Para Koleksiyonu Altın Sikke Sergisi, İstanbul 2005, s. 69-77.

Bozkurt, Nahide, Abbâsîler, İsâm Yayınları, İstanbul 2013.

Can, Mesut, Fazl Bin Sehl'in Hayatı Ve Şahsiyeti, Yayımlanmamış Yüksek Lisans Tezi, Selçuk Üniversitesi, Sosyal Bilimler Enstitüsü, Konya 2010.

Clot, Andre, Harun Reşid ve Abbâsîler Dönemi, Çev. Nedim Demirtaş, Tarih Vakfı Yurt Yayınları, İstanbul 2007.

Damalı, Atom, 150 Devlet 1500 Sultan İslam Sikkeleri, Nilüfer Damalı Eğitim Kültür ve Çevre vakfı Yayınları, İstanbul 2001.

Heideman, Stefan, "Numismatics", The New Cambridge History Of Islam, Volume 1, The Formation Of The Islamic World, Sixth To Eleventh Centuries, Edited By Chase Robinson, Cambridge University Press, 2010, s. 648-663.

Hatîb el-Bağdâdî (Ebu Bekir Ahmed b. Ali b. Sabit), Târîhu Medîneti's-Selâm ve Ahbâru Muhaddisihâ ve Zikru Kuttâniha el-Ulemâi min Gayri Ehlihâ ve Vâridihâ, Thk. Beşşâr 'Avvâd Ma'rûf, C. 14, Beyrut 2001(1422).

İbn Kesîr, El Bidâye ve'n-Nihaye Büyük İslam Tarihi, C. 10, Çev. Mehmet Keskin, Çağr1 Yayınları, İstanbul 1995.

İbnü'l-Esîr, İslam Tarihi El Kamil Fi't-Tarih Tercümesi, C. 5, 6, Çev. M. Beşir Eryarsoy, Bahar Yayınlar1, İstanbul 1991.

Kolektif, Altının İktidarı, İktidarın Altınları, Yapı-Kredi Para Koleksiyonu Altın Sikke Sergisi, Editör Oğuz Tekin, Proje Koordinatörü Şennur Şentürk, YKY, İstanbul 2005. 
Makrizî, Takiyuddin Ahmed b. Abdülkadir, Kitâbu'n-Nukûdi'l-Kadîmeti ve'l-İslâmiyye, Konstantiniyye 1298 (188/81). PDF Erişim Tarihi: 11.06.2018

(Erişim: https://ar.wikisource.org/w/index.php?title=ملف:النقود القديمة والإسلامية.pdf\&page=9

Yıldız, Hakkı Dursun, "Bermekîler”, Türkiye Diyanet Vakfi İslam Ansiklopedisi, C. 5, İstanbul 1992, s.517-520.

Y1ldı, Hakkı Dursun, "Fazl b. Sehl”, Türkiye Diyanet Vakfi İslam Ansiklopedisi, C. 12, İstanbul 1995, s. 275-276. 